Kodifikasia : Jurnal Penelitian Islam, Vol 14, No. 02 (2020), 403-424

DOI : 10.21154/kodifikasia.v14i2.2141

ISSN : 1907-6371 (Cetak)

ISSN : 2527-9254 (Online)

\title{
APLIKASI SYIRKAH BERBASIS BAGI HASIL TANGKAPAN IKAN NELAYAN: PERSPEKTIF SOSIAL EKONOMI
}

\author{
Malahayatie* dan Suryani**
}

\begin{abstract}
Abstrak:
Fenomena kemiskinan yang dialami oleh sebagian nelayan pesisir pantai Lhokseumawe disebabkan faktor ekonomi dan sosial, sehingga para nelayan tidak mampu mendapatkan pendapatan yang layak dan akses pendidikan yang memadai. Penelitian ini bertujuan untuk mengetahui praktik bagi hasil tangkapan ikan nelayan, aplikasi syirkah pada praktik bagi hasil tersebut di kalangan nelayan Kota Lhokseumawe serta melihat berbagai fenomena kemiskinan pada nelayan di Kecamatan Banda Sakti, kota Lhokseumawe Aceh. Metode dalam penelitian ini menggunakan metode kualitatif deskriptif dengan melakukan penelitian lapangan. Hasil penelitian mengungkapkan bahwa praktik bagi hasil tangkapan ikan yang ada dikalangan nelayan Kecamatan Banda Sakti melibatkan dua pihak sebagai pemberi modal yaitu toke boat dan toke bangku dan selanjutnya di kelola oleh pihak rakan meupakat beserta pawang (nahkoda laut). Aplikasi syirkah terletak pada kerjasama dan kesepakatan dari percampuran modal kedua pihak toke boat dan toke bangku yang kemudian dikelola bersama dengan pihak pengelola.
\end{abstract}

Kata Kunci: Syirkah; Bagi hasil; Nelayan Banda Sakti

* Institut Agama Islam Negeri Lhokseumawe, email: malahayatie1979@gmail.com

** Institut Agama Islam Negeri Lhokseumawe, email: suryapijar@yahoo.com 


\begin{abstract}
:
The phenomena related to the poverty experienced by most fishermen in the coastal areas of Lhokseumawe were caused by the economic and sosial factors. Thus, the fisherman were then unable to obtain reasonable income and adequate education. This research aims at revealing the profit sharing and syirkah (cooperation) practices related to the fish caught by the local fishermen in Lhokseumawe as well as the phenomena of poverty experienced by the fishermen in Banda Sakti sub-district of Lhokseumawe. This research used a descriptive-qualitative method with various research fields. The results of this research showed that the profit sharing practices related to the fish caught by the local fishermen in Lhokseumawe involved both parties consisting of capital providers called toke boet (boat owner) and toke bangku (capital owner) which were then managed by the rakan meupakat and pawang. The syirkah was practiced due to the cooperation and agreement related to the boat and capital made by toke boet and toke bangku which were mutually managed by the managers until the processes of fish caught by the local fishermen were well completed.
\end{abstract}

Keywords: Syirkah; Profit sharing, Fishermen

\title{
PENDAHULUAN
}

Indonesia merupakan negara kepulauan (archipelago state) memiliki dua pertiga wilayahnya adalah laut, sehingga dengan demikian potensi sumber daya laut sangatlah melimpah. Wilayah perairan yang berada dalam kedaulatan Negara Kesatuan Republik Indonesia dan Zona Ekonomi Eksklusif Indonesia serta laut lepas mengandung sumber daya ikan yang potensial sebagai negara maritim terbesar di dunia yang didalamnya terkandung kekayaan hayati sumber daya ikan, yang tentu akan mensejahterakan masyarakat perikanan jika dikelola dengan baik. Namun, yang terjadi sebaliknya, pada Tahun 2004 tercatat sebanyak 47 juta kelompok miskin dan sebanyak $60 \%$ diantaranya berprofesi sebagai nelayan. ${ }^{1}$

Pengaturan kegiatan manusia dalam kaitannya dengan pemanfaatan sumberdaya ikan seringkali menjadi sangat penting dan patut diutamakan. Pentingnya faktor manusia sebagai kunci sukses pengelolaan sumberdaya

${ }^{1}$ Bambang Agus Murtijo, Tambak Air Payau Budidaya Udang Dan Bandeng, 2nd ed. (Yogyakarta: Kanisius, 1992), 9.

Kodifikasia: Jurnal Penelitian Islam, Volume, 14 No. 2 Tahun 2020 
perikanan bukan terletak pada sumberdaya ikannya, tetapi terletak pada sumberdaya manusia yang memanfaatkannya. ${ }^{2}$

Hampir $85 \%$ nelayan di Indonesia didominasi oleh perikanan skala kecil yang beroperasi di sekitar perairan pantai. Kontribusi nelayan skala kecil sangat besar dalam produksi perikanan tangkap, namun nelayan skala kecil masih diidentikkan dengan kemiskinan. Hal ini menunjukkan usaha perikanan skala kecil masih tidak efiesien, dimana upaya penangkapan melebihi ketersediaan dari sumberdaya yang ada. ${ }^{3}$ Komitmen pendayagunaan sumberdaya kelautan masih kurang. Hal ini dapat dilihat dalam kenyataannya bahwa nelayan selaku aktor utama di sektor ini masih berada dibawah garis kemiskinan. ${ }^{4}$

Hasil tangkapan ikan yang belum diikuti kesejahteraan nelayan bersumber dua faktor yaitu : (1) Faktor alamiah, yakni faktor yang berkaitan dengan fluktuasi musim-musim penangkapan dan struktur alamiah sumberdaya ekonomi desa, dan (2) Faktor non alamiah yakni faktor yang berhubungan dengan keterbatasan jangkauan teknologi penangkapan, ketimpangan sistem bagi hasil dan tidak ada kepastian jaminan sosial tenaga kerja, jaringan pemasaran masih lemah dan lembaga koperasi nelayan yang ada belum berfungsi dengan baik. ${ }^{5}$

Sektor kelautan sebagai salah satu SDA yang mempunyai peranan penting dan strategis sumber daya ikan yang sangat potensial. Perikanan merupakan salah satu sektor hasil laut yang dapat memberikan manfaat terhadap ekonomi nasional. Perikanan dalam segi asupan gizi, merupakan salah satu bahan pangan protein dan bisa pula untuk membuka lapangan pekerjaan. ${ }^{6}$ Potensi itu hanya bisa dimanfaatkan oleh masyarakat nelayan yang menjadi motor penggerak pendapatan nasional dalam sektor hasil tangkap ikan, akan tetapi potensi yang ada masih belum dikelola dengan baik mengingat, masyarakat nelayan masih identik dengan kemiskinan.

2 Riesti Triyanti and Maulana Firdaus, "Tingkat Kesejahteraan Nelayan Skala Kecil Dengan Pendekatan Penghidupan Berkelanjutan Di Kabupaten Indramayu," Jurnal Sosial Ekonomi Kelautan Dan Perikanan 11, no. 1 (2016): 29-43, https://doi.org/10.15578/jsekp. v11i1.3170.

3 ES Wiyono and RI Wahju, "Perhitungan Kapasitas Penangkapan (Fishing Capacity) Pada Perikanan Skala Kecil Pantai. Suatu Penelitian Pendahuluan," in Prosiding Seminar Nasional Perikanan Tangkap (Bogor: Departemen Pemanfaatan Sumberdaya Perikanan. Fakultas Perikanan dan Ilmu Kelautan. Institut Pertanian Bogor, 2006), 381-89.

4 Triyanti and Firdaus, "Tingkat Kesejahteraan Nelayan Skala Kecil Dengan Pendekatan Penghidupan Berkelanjutan Di Kabupaten Indramayu.”

5 MA Kusnadi, Konflik Sosial Nelayan (Yogyakarta: LKIS, 2002), 50

6 Ardi Abdul Rahman and Anas Alhifni, "Analisis Kebutuhan Nelayan terhadap Pembiayaan LKMS," Jurnal Syarikah: Jurnal Ekonomi Islam 4, no. 2 (January 10, 2019): 152, https://doi.org/10.30997/jsei.v4i2.1506. 
Penyebab kemiskinan di masyarakat khususnya di pesisir disebabkan oleh keterbatasan aset yang dimiliki, yaitu: (a) Natural assets: seperti tanah dan air, karena sebagian besar masyarakat hanya menguasai lahan yang kurang memadai untuk mata pencahariannya; (b) Human assets: menyangkut kualitas sumber daya manusia yang relatif masih rendah (tingkat pendidikan, pengetahuan, keterampilan maupun tingkat kesehatan dan penguasaan teknologi); (c) Physical assets: minimnya akses ke infrastruktur dan fasilitas umum seperti jaringan jalan, listrik, dan komunikasi di pedesaan; (d) Financial assets: berupa tabungan (saving), akses untuk memperoleh modal usaha; dan (e) Social assets: berupa jaringan, kontak dan pengaruh politik, dalam hal ini kekuatan bargaining position dalam pengambilan keputusankeputusan politik.?

Wilayah Kecamatan Banda Sakti merupakan pusat ibukota Kota Lhokseumawe yang memiliki beragam kondisi sosial ekonomi. Profesi kebanyakan masyarakatnya sebagai Pegawai Negeri Sipil, pengusaha kuliner dan berbagai jenis profesi lain. Namun secara geografis Kecamatan Banda Sakti juga berbatasan dengan pesisir pantai yang menjadi sumber pencarian sebagai penangkap ikan atau nelayan. Kegiatan ini sangat dirasakan oleh para nelayan karena mereka sebagai golongan masyarakat yang menikmati dan bergantung kehidupannya dari usaha melaut.

Profesi nelayan dalam masyarakat Aceh melibatkan beberapa pihak diantaranya: 1) Pemilik kapal dan peralatan tangkapnya disebut Toke Boet. 2) Awak kapal atau nelayan buruh disebut Rakan Meupukat. 3) Penyedia modal informal atau pemilik modal yang sekaligus sebagai pedagang perantara disebut Toke Bangku. 4) Pemimpin awak kapal atau buruh nelayan disebut Pawang (Nahkoda Laut) dan pemimpin kelompok nelayan disebut sebagai Panglima Laot.

Sistem bagi hasil antara nelayan dan pemilik modal lengkap dengan hak dan kewajiban dari masing-masing pihak. ${ }^{8}$ Semua pihak inilah yang terlibat dan memainkan peran penting dalam kegiatan usaha penangkapan ikan sehingga menjadi sebuah tradisi turun menurun di Kecamatan Banda Sakti. Pekerjaan sebagai nelayan secara praktik dilihat dari dua wilayah yang berbeda dan dipimpin oleh dua panglima laot wilayah yaitu wilayah Kuala Pusong dan Kuala Mamplam. Masing-masing wilayah mempunyai praktik bagi hasil yang berbeda meskipun masih menggunakan kerjasama

7 Chriswardani Suryawati, "Memahami Kemiskinan secara Multidimensional," Jurnal Manajemen Pelayanan Kesehatan 08, no. 03 (2005): 121-29.

8 Eva Wardah, "Peran Lembaga Hukum Adat Laot Dalam Mengatur Sistem Bagi Hasil Perikanan Tangkap Antar Nelayan Dengan Pemodal Di Kabupaten Aceh Barat," Acta Aquatica 2, no. 2 (2015): 75-78.

Kodifikasia: Jurnal Penelitian Islam, Volume, 14 No. 2 Tahun 2020 
dan kesepakatan dari berbagai pihak yang berlaku secara tidak tertulis di kalangan para nelayan.

Pengembangan sektor perikanan laut sebagian nelayan di Aceh khususnya di Kecamatan Banda Sakti masih dilakukan secara tradisional. Hal ini jika tampak jelas dilihat dari peralatan-peralatan yang digunakan seperti salah satu alat pukat Aceh atau sering disebut dengan kegiatan tarek pukat. Tarek pukat merupakan suatu unit peralatan yang terdiri dari beberapa unsur atau komponen yang saling mendukung dan tidak dapat dipisahkan dari sebuah pukat dimana kegiatan ini merupakan akad kerjasama atau berkelompok yang dibantu oleh perahu yang terbuat dari kayu yang ditarik dengan tali sampai ke bibir pantai.

Selain mengembangkan sektor perikanan melalui proses tradisional, di wilayah berbeda para nelayan menggunakan kerjasama dalam lingkup yang lebih besar dengan melibatkan berbagai pihak yaitu pemilik modal, pemilik perahu/kapal besar (boat) dan panglima laot. Masalah ini menjadi penting karena nelayan kecil (khususnya buruh) adalah elemen masyarakat terbawah yang senantiasa menderita dan menjadi korban dari keserakahan "bandar besar". Kegiatan di sektor perikanan tangkap ikan ini melibatkan banyak pihak sehingga pembagian dalam sektor ekonomi khususnya bagi hasil akan semakin berkurang.

Keberadaan wilayah laut yang dimiliki Indonesia serta kandungan kekayaan sumber daya ikan maka secara logika menunjukkan terbukanya peluang kerja di sektor ini dan adanya kehidupan nelayan yang mapan. Namun dalam realitanya kehidupan nelayan masih sangat memprihatinkan. Kemiskinan masih dijumpai di daerah-daerah pesisir, nelayan rentan terhadap konflik antar mereka. Ketidakmampuan dalam memanfaatkan sumberdaya ikan bukanlah satu-satunya penyebab dalam permasalahan kemiskinan nelayan, mengingat masih banyak faktor lain satu sama lain yang saling terkait.

Nelayan di Kota Lhokseumawe seperti disebutkan diatas dalam kegiatan di sektor perikanan banyak melibatkan pihak-pihak tertentu. Walaupun dalam hubungan kerja di antara seluruh pihak terdapat perjanjian yang tidak tertulis, namun menghasilkan hak dan kewajiban yang disepakati bersama. Praktik bagi hasil tangkapan ikan di Lhokseumawe masih menggunakan proses manual tradisional dan sudah menggunakan praktik modern dimana aplikasi kerjasama dari berbagai pihak sudah mulai menggunakan perahu besar dan sarana-sarana melaut yang sudah memadai meskipun konsep kerjasama berbagai pihak dalam usaha tangkapan ikan para nelayan secara modern ini memiliki berbagai keuntungan dan resiko yang juga ikut ditanggung secara bersama. 
Berdasarkan pemaparan diatas menjadi gambaran bahwa praktik bagi hasil tangkapan ikan menggunakan konsep aplikasi Syirkah ditandai adanya percampuran modal dari berbagai pihak dan dikelola bersama oleh rakan meupakat dan dengan pawang yang bertujuan mendapatkan keuntungan bagi hasil dari setiap kerjasama yang sudah disepakati di awal. Hal ini menunjukkan diperlukan dukungan dari pemilik modal dan pemilik harta lainnya yang mempunyai kemampuan agar kerjasama usaha nelayan dapat menghasilkan keuntungan.

Fokus kajian penelitian ini terletak pada urgensi aplikasi syirkah praktik bagi hasil tangkapan ikan para nelayan yang mampu meningkatkan taraf hidup sosial ekonomi masyarakat nelayan. Hal ini menarik dikaji bahwa usaha yang dibangun dalam bentuk aplikasi syirkah bertujuan memiliki kepentingan dan kebutuhan secara bersama sehingga dapat meningkatkan taraf ekonomi para nelayan. Nelayan yang merupakan pekerja dari kegiatan usaha tangkapan ikan bisa merasakan hasil dari kegiatan kerjasama yang berbentuk syirkah. Penelitian ini juga ingin mengungkapkan praktik bagi hasil tangkapan ikan di kalangan para nelayan dan dapat menganalisis aplikasi syirkah pada praktik bagi hasil tangkapan ikan yang mampu memberi dampak positif bagi kehidupan sosial ekonomi para nelayan.

Beberapa penelitian terdahulu yang terkait dengan penelitian ini yaitu: Siti Nurmalasari, Respon Nelayan Terhadap Pola Bagi Hasil dengan Pemilik Kapal di Gampong Tanoh Anou Kec. Idi Rayeu, dengan hasil penelitian mengungkapkan bahwa pola bagi hasil yang selama ini berjalan merugikan pihak nelayan sehingga sebagaian dari mereka melakukan kecurangan dengan menjual sebagiam ikan di tengah laut sebelum hasil tangkapannya diserahkan kepada pemilik kapal. ${ }^{9}$ Perbedaan dengan penelitiian ini terletak pada akad mudharabah yang diterapkan memberi respon dari para nelayan yang cukup beresiko sehingga terjadi kecurangan.

Muhammad Irfan, Sistem Bagi Hasil pada Pelelangan Ikan di Kecamatan Galesong Utara Kabupaten Takalar dengan hasil penelitiannya menjelaskan bahwa kerjasama bagi hasil penangkapan ikan berasaskan akad perjanjian antara nelayan dan juragan dilakukan secara lisan, dengan mengikuti adat kebiasaan yang berlaku secara turun temurun. Pelaksanaan kerjasama bagi hasil tersebut terletak hanya sebatas kerja dan mendapatkan penghasilan. Hasil penelitian menyimpulkan bahwa akad perjanjian bagi hasil penangkapan ikan yang dilakukan oleh nelayan patorani adalah sah menurut hukum Islam karena telah memenuhi syarat-syarat dan rukun.

${ }^{9}$ Siti Nurmalasari, "Respon Nelayan Terhadap Pola Bagi Hasil Dengan Pemilik Kapal Di Gampong Tanoh Anou Kec. Idi Rayeu," Al-Muamalah: Jurnal Hukum Ekonomi Syariah 3(1) (2018): 2-18.

Kodifikasia: Jurnal Penelitian Islam, Volume, 14 No. 2 Tahun 2020 
Dilihat dari sistem bagi hasil maka dapat dikatakan bahwa pembagian tersebut sudah cukup adil meskipun terdapat ketidakadilan tentang kerugian dalam kerjasama bagi hasil, dalam kerjasama ini adanya hutang yang dibebankan kepada juragan. ${ }^{10}$ Fokus kajian dari segi hukum Islam menjadi aspek yang membedakan dengan penelitian ini tanpa melihat dari aspek sosial dan ekonominya.

Arnita Nucifera Nida Silmi, Eko Sri Wiyono, Sugeng Hari Wisudo, Pola Bagi Hasil Tangkapan Ikan Nelayan Pancing di Cisolok, dengan hasil penelitian menjelaskan bahwa sistem bagi hasil untuk kapal pancing di Pelabuhan Ratu adalah 60\% untuk pemilik kapal dan 40\% untuk ABK dari hasil bersih. Tahun 2015 rata-rata pendapatan nelayan berada di atas UMK Kabupaten Sukabumi. Hampir semua peraturan tentang sistem bagi hasil sudah dilaksanakan tetapi nelayan masih dalam kondisi miskin. ${ }^{11}$ Pendapatan para nelayan sudah di atas UMK Kabupaten dengan adanya pola bagi hasil tersebut dan keterkaitan kemiskinan dengan adanya pola bagi hasil tidak dibahas secara rinci menjadi hal yang membedakan dengan kajian penelitian ini.

Rolandow L. Dauhan dkk, Analisis Pendapatan dan Sistem Bagi Hasil Nelayan Jaring Insang (Gill Net) Malos 3 di Kelurahan Malalayang Satu Timur Kecamatan Malalayang Kota Manado, dimana hasil penelitian menjelaskan bahwa sistem bagi hasil kelompok nelayan menganut sistem sama rata sama rasa. Anggota kelompok yang melakukan aktivitas melaut akan mendapat bagian yang sama atas ikan hasil tangkapan maupun jumlah rupiah yang sama untuk ikan hasil penjualan. ${ }^{12}$ Penelitian ini hanya memaparkan adanya hasil dan jumlah rupiah yang didapat oleh nelayan sama rata tanpa melihat aspek kerjasama yang dibangun sangat membantu para nelayan.

Achmad Shofi Ahadian, Akad Musyarakah Antara Pemilik Kapal dan Nelayan (Studi di Desa Sumber Anyar, Kecamatan Paiton, Kabupaten Probolinggo). Hasil penelitian menjelaskan pertama: Aplikasi akad musyarakah atau sistem kerja antara pemilik kapal dan buruh nelayan cenderung bersifat kapitalis yang banyak memihak pada kelompok borjuis atau para juragan dan kurang menguntungkan pada kelompok proletar atau nelayan buruh. Kedua: Sistem bagi hasil antara pemilik kapal dan buruh nelayan

\footnotetext{
${ }^{10}$ Muhammad Irfan, "Sistem Bagi Hasil Pada Pelelangan Ikan Di Kecamatan Galesong Utara Kabupaten Takalar,” Al-Qadau 5(1) (2018).

${ }^{11}$ Arnita Nucifera Nida Silmi, Eko Sri Wiyono, and Sugeng Hari Wisudo Al Bacore, "Pola Bagi Hasil Tangkapan Ikan Nelayan Pancing Di Cisolok," Albacore 2(1) (2018): 7991.

${ }^{12}$ Rolandow L. Dauhan, Jardie A. Andaki, and Vonne Lumenta, "Analisis Pendapatan Dan Sistem Bagi Hasil Nelayan Jaring Insang (Gill Net) Malos 3 Di Kelurahan Malalayang Satu Timur Kecamatan Malalayang Kota Manado," Akulturasi: Jurnal Ilmiah Agrobisnis Perikanan 4(1) (2016): 189-96.
} 
tidak memenuhi asas-asas Syariat Islam. ${ }^{13}$ Penelitian ini mengungkapkan sistem akad musyarakah yang bersifat kapitalis dan bagi hasil yang tidak sesuai syariat Islam. Hal ini berbeda dengan penelitian penulis yang terletak pada rasa saling ridha, saling ketergantungan kepentingan dan kebutuhan sehingga memberi efek sosial ekonomi dari para pihak yang terlibat.

Metode yang penulis gunakan dalam penelitian ini melalui pendekatan kualitatif deskriptif dengan teknik pengumpulan data awal observasi langsung dengan para nelayan dan pihak-pihak yang terlibat dalam kegiatan usaha tangkapan ikan ini. Peneliti juga melakukan indepth interview secara mendalam untuk mendapatkan informasi terkait penerapan aplikasi syirkah pada praktik bagi hasil tangkapan ikan di kalangan para nelayan dilihat dari aspek sosial ekonomi.

\section{PEMBAHASAN}

\section{Praktik Bagi Hasil Tangkapan Ikan Para Nelayan Kecamatan Banda Sakti}

Manusia sebagai makhluk sosial tentu kodratnya selalu membutuhkan orang lain dalam menjalani aktivitas sehari-hari. Begitu pula dalam dunia kerja, yang membutuhkan mitra kerja untuk memperoleh keuntungan/ benefit. Adanya kebutuhan yang dirasakan oleh masing-masing elemen menciptakan hubungan kerjasama antar keduanya. ${ }^{14}$

Para nelayan yang ada di Kecamatan Banda Sakti terdiri dari beberapa kelompok nelayan. Seorang pimpinan dalam kelompok nelayan tersebut dikenal dengan nama Panglima Laot. Panglima laot dibagi menjadi 4 wilayah: 1) Panglima laot Kota, yaitu terletak di Lhok Pusong atau Kuala Pusong yang dipimpin oleh Rusli Yusuf. 2) Panglima laot Kuala Mamplam, yaitu terletak di Ujong Blang yang dipimpin oleh Yusuf Risyad. 3) Panglima laot Blang Mangat, yaitu terletak di Meuraxa. 4) Panglima laot Kuala Rancong, yaitu terletak di Rancong Kecamatan Muara Satu.

Wilayah Lhok Pusong dan Ujong Blang yang terletak di Kecamatan Banda Sakti ${ }^{15}$ menjadi fokus dari penelitian ini. Menurut informasi yang didapatkan dari Dinas Kelautan dan Perikanan Kota Lhokseumawe melalui Bapak Benny Irsal Putra sebagai Kasubbag TU UPT PPI Pusong mengatakan bahwa dinas tidak melakukan intervensi apapun terhadap nelayan dalam

${ }^{13}$ Achmad Shofi Ahadian, "Akad Musyarakah Antara Pemilik Kapal dan Nelayan (Studi di Desa Sumber Anyar, Kecamatan Paiton, Kabupaten Probolinggo)" (UIN Maulana Malik Ibrahim, 2014), xiii.

${ }^{14}$ Sari Multazam, "Sistem Bagi Hasil Nelayan Punggawa-Sawi Unit Pukat Cincin (Purse Seine) Di PPI Lonrae, Kecamatan Tanete Riattang Timur, Kabupaten Bone" (Universitas Hasanuddin, 2018).

15 Wawancara dengan Benny Irsal Putra, 30 tahun Kasubbag TU UPT PPI Pusong.

Kodifikasia: Jurnal Penelitian Islam, Volume, 14 No. 2 Tahun 2020 
tradisi mereka ketika membagi hasil tangkapan ikannya. Namun dinas hanya memberikan dan memfasilitasi para nelayan dalam bentuk wadah atau tempat yang dinamakan dengan PPI (Pangkalan Penangkapan Ikan).

Walaupun PPI sudah disediakan oleh dinas terkait, namun tetap menemukan beberapa kendala yang dihadapi oleh nelayan diantaranya adalah muara pelabuhan yang tidak mampu menangani ketika datangnya air surut dari laut sehingga tidak dapat melakukan bongkar muat dengan anak boet, selain itu sistem pelelangan ikan yang belum terorganisir dan ketersediaan bahan untuk melaut yaitu es dan air bersih masih sangat kurang serta bahan bakar solar yang langka karena tidak boleh langsung diambil ke SPBU namun hanya boleh diambil ke SPDN (Solar Paket Diesel Nelayan). Itulah beberapa kendala yang masih dihadapi oleh dinas terkait dengan PPI setempat.

Berdasarkan hasil wawancara dengan Panglima Laot Kota yaitu Bapak Rusli Yusuf yang lebih dikenal dengan sebutan Abu Li mengatakan bahwa 'tugas panglima laot adalah mengatasi berbagai sengketa dan masalah yang terjadi ketika nelayan melaut di tengah laut dan diselesaikan dengan hukum adat yang berlaku sejak turun-temurun dan masih diterapkan di wilayah laut.'

Hasil tangkapan ikan yang didapatkan oleh nelayan yang terdiri dari pawang, toke boet, toke bangku dan rakan meupakat (ABK) mendapatkan komisi-komisi tertentu setelah dikurangi pengeluaran biaya yang cukup besar berupa es batu, transportasi (solar), tempat penampungan ikan/ rumpon (tu hasan), hak sampan (boet kecil/boet cewek). Adapun tradisi bagi hasil yang melibatkan beberapa pihak tersebut adalah: 1) Pawang laot 9\%, 2) Toke boet 14\%, 3) Toke bangku 7\%, 4) Boet cewek 10\%, 5) Hak masinis $10 \%, 6)$ Rumpon $10 \%, 7)$ Rakan meupakat sisanya (40\%). ${ }^{16}$

Terkait dengan tradisi bagi hasil nelayan yang ada di Kecamatan Banda Sakti penulis juga menemui seorang tokoh adat yaitu Bapak H. M. Yunus Yacob (72 tahun), beliau merupakan anggota bidang adat istiadat di Majelis Adat Aceh (MAA) Kota Lhokseumawe. Pengelolaan bagi hasil tangkapan ikan nelayan masyarakat Kecamatan Banda Sakti masih menggunakan hukum adat dengan tradisi ketika dua perahu (boet) besar pergi melaut harus diiringi dengan beberapa perahu (boet) kecil yang membantu memberikan informasi adanya sekawanan kelompok ikan.

Istilah "pantang"17 dalam hukum adat melaut yaitu pantangan melaut pada hari Jum'at dan pantangan melaut pada hari raya Idul Fitri, Idul

${ }^{16}$ Wawancara dengan Rusli Yusuf, Panglima Laot Kota Kuala Pusong.

17 Pantang yang dimaksud di sini adalah adanya sebuah larangan bagi masyarakat Aceh menurut tradisi adat Aceh. 
Adha serta hari Tasyrik. Tradisi melaut yang ada di Aceh harus dipimpin oleh seorang Panglima Laot sebagai orang yang dimintai pendapat dan kebijakannya terutama masalah sengketa dan masalah bagi hasil dari hasil tangkapan ikan yang ada, namun apabila keputusan itu dilanggar oleh para nelayan maka akan dikenakan sanksi berupa tidak boleh melaut selama waktu tertentu yang telah disepakati. Intinya adalah hukum adat yang diberlakukan oleh para nelayan tetap menjunjung tinggi hukum syariat Islam terutama dalam konteks akad syirkah, karena tradisi ini melibatkan banyak pihak. ${ }^{18}$

Sebagian besar masyarakat nelayan di Indonesia termasuk dalam nelayan tradisional artinya mereka menggunakan peralatan dan teknologi sederhana. Dalam proses produksi perikanan para nelayan memiliki kebudayaan tersendiri yang berbeda dengan kelompok sosial lainnya. ${ }^{19}$ Hukum adat yang terjadi di tengah masyarakat menjadi bentuk aturan yang dibuat sedemikian rupa agar sesuai dengan keadaan mesyarakatnya, berisikan perintah dan larangan terhadap segala sesuatu hal agar tidak terjadinya kesenjangan didalam masyarakat hukum adat tersebut. Hukum adat biasanya tidak tertulis namun selalu hidup dan tumbuh didalam kalangan masyarakat, ini berarti hukum adat dianggap perlu oleh masyarakat.

Suatu aktivitas didalam kalangan masyarakat tidak terlepas dari kebiasaan apa yang telah dilakukan oleh masyarakat lebih dahulu. Ini tidak akan jauh perbedaannya, sehingga telah dapat dikatakan sebagai adat, baik itu dapat dilihat didalam kalangan masyarakat bermata pencaharian seperti melaut atau nelayan, tentu ada kebiasaan yang selalu dilakukan oleh leluhur dahulu didalam praktik mencari ikan di laut agar keseimbangan alam selalu terjaga, lembaga adat yang membidangi perikanan dan kelautan di Aceh yaitu lembaga adat Panglima Laot. Agar tidak punah dan hilang ditelan masa, maka organisasi Panglima Laot mulai dibentuk pada musyawarah Panglima Laot se Aceh di Langsa dan Banda Aceh. ${ }^{20}$ Bagi masyarakat Aceh keberadaaan Lembaga Hukum Adat Laot khususnya dalam hal pengelolaan sumberdaya kelautan (perikanan) mempunyai peranan yang sangat penting. ${ }^{21}$

${ }_{18}$ Wawancara dengan H. M. Yunus Yacob (72 tahun), Anggota Majelis Adat Aceh Kota Lhokseumawe Bidang Adat Istiadat.

${ }^{19}$ Kusnadi. "Keberadaan Nelayan dan Dinamika Ekonomi Pesisir". (Yogyakarta: Ar-Ruzz Media, 2009), 27.

${ }^{20}$ Rahmat Fitrah, "Kedudukan Panglima Laot Lhok dalam Kalangan Masyarakat Nelayan (Studi Kasus Kecamatan Meureubo, Aceh Barat)," Ius Civile: Refleksi Penegakan Hukum Dan Keadilan 1, no. 1 (October 29, 2018).

${ }^{21} \mathrm{H}$, Nya'pha. "Panglima Laot; Peranan dalam Lembaga Adat Laot (Menuju Hukum Adat yang Berkekuatan Hukum Tetap), Makalah disampaikan pada Lokakarya yang dilaksanakan oleh Panglima Laot se- Aceh di Sabang, 2001. 
Peranan Lembaga Hukum Adat Laot dalam masyarakat Aceh memandang Panglima Laot itu sebagai pemimpin lembaga adat. Adat tersebut berkuasa mengatur eksploitasi lingkungan laut didalam wilayah laut yang menjadi kekuasaannya. Kekuasaan mengatur lingkungan laut dalam wilayah juridiksinya bersifat otonom tidak tergantung kepada kekuasaan manapun juga. Kekuasaan Panglima Laot meliputi tiga bidang yaitu kemanan dilaut, bidang sosial warga, persekutuan dan bidang pemeliharaan lingkungan laut. ${ }^{22}$

Wawancara penulis dengan nelayan yang berada di wilayah Kuala Pusong yang bernama Syahrizal Rusli atau biasa dipanggil Pawang Jal. Ia menjelaskan bahwa tradisi menangkap ikan di wilayah Pusong berdasarkan jenis ikan yang dibedakan menjadi 2 yaitu ikan kecil (teri dan sejenisnya) dan ikan besar (tongkol dan sejenisnya). Untuk wilayah ikan kecil 15 mil dari garis pantai dan biaya operasional yang biasanya dikeluarkan mencapai 20 hingga 40 juta per hari, berangkat melaut pada siang hari pukul 14.00 sampai keesokan harinya. Pembagian hasil tangkapan ikan kecil ini dibagi 3 bagian, 2 bagian untuk toke boet dan 1 bagian untuk rakan meupakat setelah dikurangi biaya operasional yang terdiri dari biaya es $10 \%$, komisi $20 \%$, boet $\mathrm{kecil} /$ boet cewek $10 \%$ dan rumpon $10 \%$.

Wilayah ikan besar 30 mil dari garis pantai berdasarkan keterangan dari syahbandar, 25-200 mil perjalanan sehari semalam (15-18 jam) dan biaya operasional yang biasanya dikeluarkan mencapai 150 hingga 200 Juta selama 1 minggu (7 hari). Hasil tangkapan ikan besar di wilayah ini mencapai 5070 fiber. Pembagian hasil tangkapan ikan besar ini dibagi 3 bagian, 2 bagian untuk toke boet dan 1 bagian untuk rakan meupakat setelah dikurangi biaya operasional yang terdiri dari biaya es 10\%, komisi 30-35\%, boet kecil/boet cewek 10\% dan rumpon 10\%. Selain mendapatkan bagi hasil 1 bagian, rakan meupakat juga mendapatkan hak ikan besar yang dapat mereka jual sendiri berdasarkan kesepakatan dengan toke boet selama toke boet tersebut memberikan hasil tangkapan ikannya sesuai dengan banyaknya hasil ikan yang didapatkan. Begitu juga dengan boet kecil/cewek akan mendapatkan hak berupa hasil ikan seperti rakan meupakat juga, semua itu tergantung dari kebijakan toke boet yang bersangkutan. ${ }^{23}$

Selanjutnya penulis melakukan wawancara dengan nelayan yang berada di wilayah Kuala Mamplam Ujong Blang yang bernama M. Jafar Wahab (38 tahun). Menurut beliau Panglima Laot yang berada di wilayah ini sedang dalam kondisi sakit (stroke) sehingga penulis tidak dapat

22 Y. Adami, "Aspek Kelembagaan Masyarakat Nelayan Dalam Pengembangan Wilayah Di Kabupaten Aceh Utara" (Institut Pertanian Bogor, 1995).

${ }^{23}$ Wawancara dengan Syahrizal Rusli (50 tahun), Pawang Laot dan Toke Boet Wilayah Kuala Pusong. 
melakukan wawancara langsung dengan panglima laot tersebut. Wilayah Kuala Mamplam Ujong Blang tidak memiliki PPI (Pangkalan Pelelangan Ikan) namun yang ada adalah TPI (Tempat Pelelangan Ikan) sebagai wadah melakukan transaksi-transaksi jual beli ikan berskala kecil. Selain itu tradisi melaut nelayan yang ada di wilayah ini masih minim karena masih menggunakan alat melaut yang sangat tradisional yaitu sampan dan tarik pukat.

Bagi hasil yang diperoleh oleh pihak-pihak yang terkait biasanya dibagi 3 bagian yaitu 2 bagian pemilik sampan dan 1 bagian rakan meupakat. Itupun setelah dikurangi dengan segala biaya operasional yang dikeluarkan, dan hasil yang diberikan kepada rakan meupakat di wilayah ini tidak menentu tergantung hasil tangkapan bahkan pernah tidak mendapatkan hasil sama sekali. ${ }^{24}$ Tradisi tarek pukat dapat dikatakan bahwa sudah menjadi warisan dari nenek moyang masyarakat Aceh yang tinggal di pesisir pantai. Praktik tarek pukat ini diteruskan oleh masyarakat Aceh khususnya nelayan Kecamatan Banda Sakti dan menjadi profesi agar dapat menghasilkan pendapatan sehari-hari. ${ }^{25}$

Praktik tarek pukat yang dikembangkan oleh nelayan di wilayah Ujong Blang karena daerah ini tidak mempunyai PPI (Pangkalan Pelelangan Ikan), maka mereka hanya menggunakan boet-boet (perahu) kecil saja ketika melaut. Selain itu mereka juga menggunakan jaring pukat untuk menangkap ikan dalam skala kecil. ${ }^{26}$

Kegiatan tarek pukat berlangsung pada para nelayan yang ingin mencari nafkah sebagai profesi dan keahlian yang dimilikinya berupa tenaga dalam menarik pukat yang dilabuhkan dari bibir pantai sampai dengan jarak 200 meter. Hasil tangkapan ikan dari tarek pukat ini dapat diperjualbelikan dan hasilnya akan dibagi diantara sesama pihak-pihak yang terlibat. ${ }^{27}$ Profesi sebagai nelayan khususnya sebagai rakan dalam tarek pukat bertujuan untuk memenuhi kebutuhan hidup sehari-hari sebagai kepala keluarga dan ingin membantu orang tua yang sudah tidak mampu lagi bekerja. ${ }^{28}$

Adapun praktik bagi hasil dimisalkan hasil tangkapan ikan yang didapatkan dari tarek pukat pagi dijual sehingga mendapatkan uang $\mathrm{Rp}$ 1.000.000,-, maka akan dibagikan berdasarkan kesepakatan dan ketentuan yang ada yaitu:

Uang pukat

Uang toke bawa ikan

Rp. 200.000,-

Rp. 200.000,-

${ }^{24}$ Wawancara dengan M. Jafar Wahab (38 tahun), Nelayan wilayah Ujong Blang.

25 Wawancara dengan Zakaria, Tokoh Masyarakat.

${ }^{26}$ Wawancara dengan Nabawi, Rakan Tarek pukat Ujong Blang.

27 Wawancara dengan Umam, Tokoh Masyarakat Hagu Selatan.

28 Wawancara dengan Doyok, Toni, Wais dan Arman, Rakan Tarek pukat Ujong Blang.

Kodifikasia: Jurnal Penelitian Islam, Volume, 14 No. 2 Tahun 2020 
Teumarek Rp. 200.000,-

$\begin{array}{lll}\text { Uang Sarapan } & \text { Rp. } & 50.000,- \\ \text { Hasil bersihnya } & \text { Rp. } & 650.000,-\end{array}$

(untuk 5 orang) $=$ Rp. 40.000,-

Pembagian yang akan diberikan kepada rakan dan pawang Rp. 650.000,$\mathrm{x} 8$ orang $=\mathrm{Rp} 81.250$,- pawang dan rakan pukat mendapatkan perolehan banyak karena menjalankan tarik pukat dari awal pukat dilabuhkan sampai akhir sedangkan teumarek mendapatkan sedikit perolehan karena menarik pukatnya saat pukat hampir sampai di bibir pantai.

Adapun bagi hasil yang didapatkan dari tarik pukat malam sejumlah Rp 2.000.000,- (masih kotor), maka akan dibagikan dengan persentase sebagai berikut:

Uang pukat

Uang toke bawa ikan

Teumarek
Rp. 200.000,-

Rp. 200.000,-

Rp. 300.000,-

(untuk 10 orang) $=$ Rp. 30.000,-

$\begin{array}{lll}\text { Uang Sarapan } & \text { Rp. } & 50.000,- \\ \text { Hasil bersihnya } & \text { Rp. } & 1.250 .000,-\end{array}$

Rakan dan pawang sebanyak 8 orang masing-masing akan menerima $=$ Rp. 156.250,- apabila terjadi kerugian seperti tidak mendapatkan hasil dari tarek pukat mungkin saja angin, ombak besar dan putus pukat saat dilabuhkan yang menyebabkan kerugian dari tarik pukat, maka tidak mendapatkan apa-apa dari kegiatan tarik pukat.

Syarat yang digunakan oleh pawang pukat kepada rakan dan teumarek adalah praktis yaitu tidak ada persyaratan khusus. Pawang membolehkan anak-anak atau orang tua yang berumur lanjut tarek pukat untuk menambahkan anggota agar saat dalam bekerja dapat cepat selesai dengan tenaga yang ada pada setiap anggotanya.

Sistem kerja sama yang diterapkan oleh pawang pukat kepada rakan dan temarek saat melakukan tarek pukat adalah kekompakan dalam tim, pengarahan yang cukup berpengalaman dalam tarek pukat karena tarik pukat sangat melelahkan yang dikerjakan sampai 2 jam atau lebih jadi membutuhkan tenaga yang kuat agar pekerjaan yang dijalankan cepat selesai dan strategi yang cukup agar dapat dijalankan dengan tepat dan praktis. ${ }^{29}$ Kerjasama bagi hasil penangkapan ikan perjanjian antara nelayan dan juragan adalah dilakukan secara lisan dengan mengikuti adat kebiasaan yang berlaku turun-temurun dan dalam pelaksanaan kerjasama bagi hasil tersebut hanya sebatas kerja untuk mendapatkan hasil.

${ }^{29}$ Wawancara dengan Ilyas, Pawang di Gampong Hagu Selatan. 
Praktik bagi hasil yang digambarkan di atas menunjukkan sebuah model bagi hasil dimana kesepakatan sudah menjadi hal yang lumrah di taati secara bersama. Pihak yang terlibat sudah memiliki pengalaman dalam pelaksanaan kegiatan usaha melaut karena sudah menjadi profesi rutin di daerah pesisir Kecamatan Banda Sakti. Kondisi kedua wilayah pesisir pantai yang berbeda menggambarkan bahwa meskipun memiliki perbedaan pada sistem dan prosedur usaha namun keduanya sama-sama mempunyai kebutuhan kerjasama usaha demi mempertahankan sumber penghasilan dari usaha tersebut.

Keterkaitan erat antara kepentingan dan kebutuhan masyarakat nelayan akan sebuah kerjasama yang berwujud dari praktik bagi hasil tarek pukat membentuk sebuah model mata rantai kepentingan dan kebutuhan dari masyarakat nelayan setempat. Para nelayan dan pihak lain yang terlibat memiliki hak, tanggungjawab serta kewajiban yang telah dipahami bersama. Hal ini ditandai adanya keseriusan dan kesungguhan dari semua pihak dalam mematuhi dan mentaati aturan dalam proses kegiatan usaha melaut ini.

\section{Aplikasi Syirkah Pada Praktik Bagi Hasil Tangkapan Ikan Nelayan di Kecamatan Banda Sakti}

Setiap kerjasama antara dua orang atau lebih mempunyai suatu tujuan yang dimungkinkan akan lebih mudah dicapai apabila dilaksanakan bersama. Kerjasama yang dilakukan dua orang atau lebih itu melibatkan beberapa pihak seperti penanam modal (shahibul mal) atau yang disebut dengan investor dan pengelola (buruh kerja) yang disebut mudharib.

Masyarakat nelayan di Kecamatan Banda Sakti seperti yang telah disebutkan di atas dalam kegiatan disektor perikanan tangkap ikan melibatkan banyak pihak khususnya: 1) Pemilik perahu (toke boet) dan peralatan tangkapnya. 2) Rakan meupukat atau nelayan buruh. 3) Penyedia modal informal atau pemilik modal disebut toke bangku yang sekaligus sebagai pedagang (perantara) ikan.

Kesepakatan dalam pengelolaan dipandang sebagai suatu kerjasama antara pemilik modal, pemilik perahu dan buruh nelayan, kesepakatankesepakatan yang diperlukan adalah kesesuaian dan keadilan, dan yang terpenting dalam sebuah kerjasama adalah hak dan kewajiban dari masingmasing pihak harus dinyatakan dengan jelas dalam penyajian kerjasama tersebut. Adapun hak dan kewajiban masing-masing pihak adalah sebagai berikut: 


\section{1) Hak dan Kewajiban Toke Boet (Pemilik Perahu)}

Adapun hak pemilik perahu toke boet (pemilik perahu) diantaranya adalah: a) Memperoleh keuntungan dari hasil usaha bersama, yang dibagi dalam tiga bagian yakni 1 untuk pemilik perahu dan yang dua untuk buruh nelayan. b) Mendapat komisi dari pemilik modal berupa 1 bungkus rokok (kondisional). Sedangkan Kewajiban toke boet (pemilik perahu) sebagai berikut: a) Membayar pajak ${ }^{30}$ pada petugas Tempat Pelelangan Ikan (TPI) b) Menyediakan perahu, jaring/pukat beserta alat tangkapnya, c) Menyediakan bahan bakar minyak, seperti solar, bensin, d) Es, kulkas box untuk mengawetkan hasil tangkapan dan, d) Setiap satu tahun sekali memberikan tunjangan berupa sarung, beras, dan sebagainya (biasanya pemberian ini diberikan menjelang hari Raya Idul Fitri).

2) Hak dan Kewajiban Toke Bangku (pemilik modal)

Adapun hak pemilik modal adalah sebagai berikut: a) Mengambil fee $15-20 \%$ sebelum dibagi tiga bagian, b) Menentukan, mencari pasar ikan, c) Menentukan harga jadi ikan. Sedangkan kewajiban pemilik modal (toke bangku) adalah sebagai berikut: a) Penyedia/penyandang modal. b) Memberikan pinjaman ikatan pada pemilik perahu dan juga buruh nelayan. c) Memberikan tunjangan berupa rokok 1 press pada saat mengikat $m$ ui $^{31}$ yang dilakukan beberapa bulan sekali atau pada saat mereka tidak bekerja karena tidak musim ikan (paceklik). d) Hak dan Kewajiban Rakan Meupukat.

Nelayan memiliki hak buruh iantaranya sebagai berikut: a) Berhak menerima upah yang berupa ikan bukan uang, yang dibagi dalam tiga bagian (telon) yakni 1 untuk pemilik perahu dan yang dua untuk buruh nelayan, yang dua ini masih dibagi lagi sesuai dengan jumlah anggota. b) Mereka harus disediakan akomodasi yang layak dan kesehatan yang efesiensi agar kerja mereka tidak terganggu. c) Tidak boleh mempekerjakan mereka melebihi kemampuan fisiknya, jika suatu waktu ia diberi pekerjan yang lebih berat maka ia harus diberi bantuan dalam bentuk beras atau modal yang lebih banyak. Sedangkan kewajiban buruh nelayan adalah sebagai berikut: a) Bertanggung jawab atas pekerjaan, b) Memberikan hasil terbaik buat mitra kerja atau majikannya.

Apabila pada bulan baik yaitu saat cuaca tenang para nelayan yang ada di Kecamatan Banda Sakti yang meliputi 2 wilayah ini akan melaut

\footnotetext{
${ }^{30}$ Pajak adalah pemumgutan uang dari sebagian hasil penjualan ikan yang diperuntukkan untuk dana sosial atau pajak penghasilan (semacam retribusi).

${ }^{31} \mathrm{Mui}$ (pelampung) adalah anyaman yang dilakukan untuk memperbaiki jaring yang rusak.
} 
4 sampai 6 kali dalam sebulan. Pendapatan yang diperoleh setiap melaut hasil yang diperoleh tidak menentu kadang-kadang melimpah dan sering kali juga tidak membawa hasil. Sekali melaut apabila menggunakan kapal besar dapat menghasilkan pendapatan dari hasil lelang sebesar 7-10 juta rupiah, total pendapatan itu harus dikurangi dengan biaya pembekalan yang meliputi solar, es batu, air bersih, akomodasi ABK sebesar 1-2 juta rupiah. Pendapatan sebagai hasil bersih dapat dikatakan antara 5-8 juta rupiah. Tradisi praktik tarek pukat, tidak selamanya mendapatkan hasil yang banyak tergantung pada kondisi cuaca dan hasil laut.

Permasalahan lain dalam kerjasama bagi hasil perikanan, dimana pihak shahibul mal yaitu toke boet dan toke bangku mempunyai otoritas tinggi tapi mereka juga mempunyai kewajiban yang tidak ringan seperti menanggung biaya perawatan perahu beserta alat-alat penangkap ikan dan konsumsi rakan meupukat (ABK) selama berlayar. Modal yang harus disediakanpun bagi pihak toke bangku tidak sedikit, hal ini dapat dilihat bahwa sebuah kapal besar (boet besar) serta peralatannya bisa mencapai harga Rp 200- Rp 400 Juta, sedangkan untuk kapal kecil yang siap melaut harganya sekitar Rp 50 Juta. Namun demikian pilihan menjadi toke boet dan toke bangku tetap lebih menguntungkan karena mereka mampu mengelola keuangan untuk mengembangkan usaha dengan membeli kapal baru.

Modal yang ditanam dalam waktu beberapa tahun dapat kembali untuk membeli kapal baru dan bisa mengembangkan usaha. Berbeda dengan rakan meupakat (ABK), tidak banyak mengalami perubahan sehingga mereka umumnya tetap menjadi buruh walaupun mereka tetap mensyukuri karena upah atau pendapatan dari hasil tangkapan ikan ini adalah hasil usaha secara turun-temurun dan sudah menjadi profesi warisan. Konflik dalam praktik bagi hasil tangkapan ikan para nelayan di dua wilayah ini mungkin saja bisa terjadi yang bisa diselesaikan oleh panglima laot masingmasing wilayah. Nelayan juga harus menaati dan mematuhi dengan sanksi yang diberikan.

Praktik tarek pukat yang ada di wilayah Ujong Blang merupakan akad kerjasama antara pawang pukat dengan rakan teumarek dalam melabuhkan pukatnya di pantai dan akan ditarik bersama-sama dengan tenaga yang diperoleh dari setiap anggota tarekpukat. Penerapan kerjasama ini melibatkan kurang lebih 8 orang rakan dan 5 orang teumarek dalam melakukan tarek pukat dengan kesepakatan bersama setelah akad digunakan. Apabila pawang telah mengajak rakannya untuk melaut dan disetujui oleh para rakan maka kegiatan tarek pukat akan dilaksanakan. Namun apabila rakan tidak menjawab atau hanya menggeleng saja berarti kegiatan tarek pukat dibatalkan dan akan dicari rakan yang lain, karena kegiatan tarek pukat ini 
tidak mengandung unsur paksaan tetapi niat yang ikhlas dan tulus dalam bekerjasama untuk mendapatkan hasil. Wujud kerjasama inilah yang juga menerapkan aplikasi syirkah karena melibatkan 2 orang atau lebih.

Aplikasi syirkah pada praktik bagi hasil tangkapan ikan di kalangan nelayan adalah adanya percampuran modal antara toke bangku dan toke boet dan kemudian dikelola oleh rakan meupakat beserta pawang (nakhoda laut) dan mereka sebagai mudharib. Kesepakatan dan kerjasama yang dilakukan oleh pihak-pihak yang disebut di atas merupakan hubungan kerja atas kebiasaan adat istiadat daerah setempat yang didasari oleh rasa saling percaya walaupun terdapat juga perselisihan atau konflik antara pihak-pihak terkait yang langsung diselesaikan oleh panglima laot setempat. Panglima laot berperan dalam mengelola konflik diselesaikan dengan musyawarah dan mufakat sehingga para pihak yang saling berselisih dapat rukun kembali dengan menerima hasil keputusan panglima laot.

Prinsip dasar bekerja di kalangan nelayan didasarkan pada asas saling membantu yang dilandasi dengan semangat gotong royong dan kebersamaan. Namun, dalam hubungan kerja diantara seluruh pihak yang terkait terdapat perjanjian yang tidak tertulis, bisa saja menghasilkan hak dan kewajiban yang sudah disepakati bersama. Hal ini sesuai dengan penelitian terdahulu yaitu bentuk perjanjian bagi hasil perikanan adalah perjanjian lisan, namun telah memenuhi syarat sah perjanjian yakni, adanya kesepakatan, kecakapan, suatu hal tertentu dan sebab yang halal. Awal mula terjadinya perjanjian bagi hasil perikanan, adalah ketika anak buah kapal menawarkan diri kepada pemilik kapal maupun pemilik kapal mencari anak buah kapal untuk menjalankan kapal milik pemilik kapal. ${ }^{32}$

Kenyataannya pada praktik bagi hasil perikanan di kalangan nelayan Kecamatan Banda Sakti para pengelola (mudharib) secara bersama-sama akan mengambil keuntungan apabila hasil tangkapan ikannya mendapatkan keuntungan, selain itu pihak pengelola (mudharib) juga akan menanggung kerugian jika hanya mendapatkan hasil tangkapan ikan yang sedikit.

Praktik bagi hasil tangkapan ikan yang ada di kalangan nelayan Kecamatan Banda Sakti termasuk dalam katagori syirkah 'uqud dimana pihak-pihak terkait yaitu antara toke boet, toke bangku, pawang dan rakan meupakat (ABK) melakukan perjanjian (kerjasama) walaupun tidak tertulis untuk mendapatkan hasil berupa keuntungan atau kerugian yang akan ditanggung bersama. Bentuk syirkah 'uqud tersebut identik dengan syirkah al-inan dan syirkah al-mufawadah.

${ }^{32}$ Danu Wiki Widiantoro, "Analisis Perjanjian Bagi Hasil Perikanan Antara Pemilik Kapal Dengan Anak Buah Kapal Di Kabupaten Batang" (Universitas Muhammadiyah Surakarta, 2018). 


\section{Kondisi Sosial Ekonomi Para Nelayan}

Fenomena sosial ekonomi para nelayan di Kota Lhokseumawe masih rentan pada kondisi di bawah garis kemiskinan. Nelayan juga masih dianggap masyarakat dengan status sosial rendah karena tingkat pendidikan mereka rata-rata hanya tamat Sekolah Dasar yang lebih mengandalkan tenaga fisik menjadi buruh atau tenaga harian dalam usaha tangkapan ikan ini. Pendapatan nelayan dengan sistem tradisional tarek pukat hanya mampu mencukupi bagi kebutuhan pokok perharinya. Sedangkan pada sistem modern yang melibatkan pihak penyedia modal dan peralatan laut, sistem ini menghasilkan pendapatan usaha relatif lebih besar.

Kerjasama tangkapan ikan praktik bagi hasil memiliki manfaat yang berarti dan sangat membantu dalam menunjang taraf kehidupan ekonomi. Hal ini dimaknai dengan keikutsertaan yang diiringi rasa ketergantungan nelayan akan kerjasama ini dengan mendapatkan bagi hasil yang sudah cukup bagi nelayan. Nelayan sangat menyadari adanya keterbatasan pendidikan juga keterbatasan dalam beradaptasi pada kemajuan teknologi dimana sistem kerjasama sudah ikut melibatkan sistem modern dengan menggunakan kapal besar dan alat alat teknologi lainnya dalam melaut. Bahkan dalam hasil penelitian terdahulu disebutkan tentang rendahnya tingkat pendidikan akan berdampak pada sulitnya nelayan dalam menerima teknologi baru akibat produksi hasil tangkapan sulit juga mengalami peningkatan. ${ }^{33}$

Kalangan nelayan sebagai pekerja yang mendapatkan porsi bagian yang lebih minim dibandingkan para pemilik modal dan pemilik kapal, setidaknya para nelayan sangat terbantu dengan kerjasama ini. Disamping memiliki porsi bagi hasil dari hasil tangkapan ikan, para nelayan juga dapat menjual kembali ikan-ikan tersebut secara retail pada pasar ikan tradisonal baik itu di dalam Kecamatan Banda Sakti maupun di luar daerah Kecamatan. Hal ini yang memiliki dampak positif bagi peningkatan taraf ekonomi para nelayan jika mereka produktf dalam kerjasama tersebut. Perjanjian yang selama ini tercipta dari asas ta'awun dimana semua lapisan masyarakat membutuhkan satu sama lainnya walaupun kesepakatan ini tidak tertulis namun menjadi kepercayaan berbagai pihak.

Senada dengan hasil penelitian lainnya bahwa proses perjanjian bagi hasil di kalangan nelayan bukanlah sebuah proses yang ketat dengan bentuk tertulis, tetapi hanyalah sebuah perjanjian tidak tertulis yang dianggap sebagai kebiasaan yang telah turun temurun. Awal perjanjian

${ }^{33}$ Danies Satyarta Pratama, "Analisis Pendapatan Nelayan Tradisional Pancing Ulur Di Kecamatan Manggar, Kabupaten Belitung Timur," Jurnal Perikanan Dan Kelautan 3(3) (2012): 107-16. 
diawali dengan ajakan atau pemberitahuan kepada ABK mengenai kapan akan berangkat melaut. Sementara akhir perjanjian bagi hasil adalah saat adanya pembagian upah yang diterima oleh ABK. ${ }^{34}$

Keberlangsungan aplikasi syirkah yang dibangun pada praktik bagi hasil tangkapan ikan di kalangan nelayan sudah terbukti mampu meningkatkan taraf hidup sosial ekonomi masyarakat setempat bahwa keluarga para nelayan mulai konsentrasi dengan pendidikan anak anak mereka ke jenjang yang lebih tinggi, kepedulian akan kesehatan yang cenderung meningkat, serta sudah mampu memiliki tempat tinggal sendiri.

Peningkatan kerjasama yang terjalin pada praktik bagi hasil tangkapan ikan agar dapat saling mengambil manfaat untuk memudahkan setiap kegiatan usaha yang ada di masyarakat pesisir pantai Kecamatan Banda Sakti. Tradisi dan budaya kerjasama praktik aplikasi syirkah dapat menjadi penyemangat bagi nelayan dalam meningkatkan kebutuhan kehidupan sehari-hari.

\section{PENUTUP}

Artikel tentang aplikasi syirkah pada praktik bagi hasil tangkapan ikan di kalangan nelayan ini memberikan kesimpulan yaitu: Pertama, Praktik bagi hasil perikanan yang ada di kalangan nelayan Kecamatan Banda Sakti dilihat dari 2 wilayah yang berbeda dan dipimpin oleh 2 panglima laot wilayah yaitu wilayah Kuala Pusong dan Kuala Mamplam. Masing-masing wilayah mempunyai praktik bagi hasil yang berbeda. Praktik kerjasama bagi hasil tangkapan ikan di wilayah Kuala Pusong berskala besar karena melibatkan banyak pihak yaitu toke boet (pemilik boet), toke bangku (pemilik modal), pawang (nakhoda) dan rakan meupakat (ABK) serta perahu yang digunakan juga beberapa jenis yaitu perahu skala sedang dan skala besar.

Kerjasama bagi hasil antara berbagai pihak dapat dikatakan hanya didasarkan pada kebiasaan atau adat yang berlaku meskipun tidak dalam bentuk perjanjian tertulis. Kebiasaan itu meliputi bagian toke boet atau toke bangku akan lebih banyak dibandingkan dengan pawang dan rakan meupakat, hal demikian sangat dimaklumi karena pemilik perahu dan pemilik modal cukup banyak mengeluarkan biaya modal. Pawang dan rakan meupakat akan menerima dengan lapang dada berapapun hasil yang diberikan setelah dikurangi berbagai biaya operasional. Setiap toke boet dan toke bangku juga mempunyai kebijakan tersendiri dalam membagikan hasil tangkapan ikan dan bisa berbeda-beda dari setiap toke boet dan toke bangku.

${ }^{34}$ Agus Sudaryanto, "Praktik Bagi Hasil Perikanan Di Kalangan Nelayan Pandangan Wetan, Rembang, Jawa Tengah,” Mimbar Hukum 21(3) (2009): 409-28. 
Kedua, Masyarakat nelayan di Kecamatan Banda Sakti seperti yang telah disebutkan di atas dalam kegiatan di sektor perikanan tangkap ikan melibatkan banyak pihak diantaranya pemilik perahu (toke boet) dan peralatan tangkapnya, penyedia modal informal atau pemilik modal disebut toke bangku yang sekaligus sebagai pedagang (perantara) ikan, pawang (nakhoda), rakan meupukat atau nelayan buruh.

Aplikasi syirkah pada praktik bagi hasil tangkapan ikan di kalangan nelayan menggambarkan adanya percampuran modal antara toke bangku dan toke boet untuk kemudian dikelola oleh rakan meupakat beserta pawang (nakhoda laut) yang disebut sebagai mudharib. Kesepakatan dan kerjasama yang dilakukan merupakan hubungan kerja atas kebiasaan adat istiadat daerah setempat yang didasari oleh rasa saling percaya walaupun terdapat juga perselisihan atau konflik yang langsung diselesaikan oleh panglima laot setempat. Kehadiran panglima laot dapat menyelesaikan konflik dengan musyawarah dan mufakat sehingga para pihak yang berselisih dapat rukun kembali dengan menerima hasil keputusan panglima laot.

\section{Saran}

Penelitian ini menyarankan kepada dinas terkait agar dapat mendirikan pangkalan pendaratan ikan di wilayah Kuala Mamplam Ujong Blang sehingga para nelayan dapat melakukan transaksi jual beli ikan dalam skala yang lebih besar. Pangkalan Pendaratan ikan merupakan prasarana penangkapan yang diperuntukkan bagi nelayan skala usaha kecil dalam rangka mendukung pengembangan ekonomi perikanan, dan jasa untuk memperlancar kegiatan usaha perikanan serta mendukung pelaksanaan program otonomi daerah. Pangkalan Pendaratan Ikan seringkali menjadi barometer majunya perikanan di suatu daerah atau wilayah karena kita dengan cepat melihat perkembangan unsur-unsur yang berperan dalam usaha perikanan seperti ikan, kapal perikanan, alat penangkapan ikan, nelayan, pengusaha perikanan dan pasar ikan.

Pangkalan pendaratan ikan tersebut tentu akan memberikan manfaat dalam mengelola hasil sumberdaya ikan dan dapat mendistribusikan hasil tangkapan ikan secara cepat sehingga penghasilan nelayan akan bisa ditingkatkan serta ruang lingkup pekerjaan nelayan juga bertambah besar. 


\section{DAFTAR RUJUKAN}

Adami, Y. "Aspek Kelembagaan Masyarakat Nelayan Dalam Pengembangan Wilayah Di Kabupaten Aceh Utara." Institut Pertanian Bogor, 1995.

Ahadian, Achmad Shofi. "Akad Musyarakah Antara Pemilik Kapal Dan Nelayan (Studi Di Desa Sumber Anyar, Kec. Paiton, Kabupaten Probolinggo)." UIN Maulana Malik Ibrahim, 2014.

Dauhan, Rolandow L., Jardie A. Andaki, and Vonne Lumenta. "Analisis Pendapatan Dan Sistem Bagi Hasil Nelayan Jaring Insang (Gill Net) Malos 3 Di Kelurahan Malalayang Satu Timur Kecamatan Malalayang Kota Manado." Akulturasi: Jurnal Ilmiah Agrobisnis Perikanan 4(1) (2016): 189-96.

Fitrah, Rahmat. "Kedudukan Panglima Laot Lhok dalam Kalangan Masyarakat Nelayan (Studi Kasus Kecamatan Meureubo, Aceh Barat)." Ius Civile: Refleksi Penegakan Hukum Dan Keadilan 1, no. 1 (October 29, 2018). http://jurnal.utu.ac.id/jcivile/article/view/545.

Irfan, Muhammad. "Sistem Bagi Hasil Pada Pelelangan Ikan Di Kecamatan Galesong Utara Kabupaten Takalar.” Al-Qadau 5(1) (2018).

Kusnadi. Keberadaan Nelayan Dan Dinamika Ekonomi Pesisi. Yogyakarta: ArRuzz Media, 2009.

Kusnadi, MA. Konflik Sosial Nelayan. Yogyakarta: LKIS, 2002.

Multazam, Sari. "Sistem Bagi Hasil Nelayan Punggawa-Sawi Unit Pukat Cincin (Purse Seine) Di PPI Lonrae, Kecamatan Tanete Riattang Timur, Kabupaten Bone." Universitas Hasanuddin, 2018.

Murtijo, Bambang Agus. Tambak Air Payau Budidaya Udang Dan Bandeng. 2nd ed. Yogyakarta: Kanisius, 1992.

Nurmalasari, Siti. "Respon Nelayan Terhadap Pola Bagi Hasil Dengan Pemilik Kapal Di Gampong Tanoh Anou Kec. Idi Rayeu." Al-Muamalah: Jurnal Hukum Ekonomi Syariah 3(1) (2018): 2-18.

Pratama, Danies Satyarta. "Analisis Pendapatan Nelayan Tradisional Pancing Ulur Di Kecamatan Manggar, Kabupaten Belitung Timur." Jurnal Perikanan Dan Kelautan 3(3) (2012): 107-16.

Rahman, Ardi Abdul, and Anas Alhifni. "Analisis Kebutuhan Nelayan terhadap Pembiayaan LKMS." Jurnal Syarikah: Jurnal Ekonomi Islam 4, no. 2 (January 10, 2019): 152. https://doi.org/10.30997/jsei.v4i2.1506. 
Silmi, Arnita Nucifera Nida, Eko Sri Wiyono, and Sugeng Hari Wisudo Al Bacore. "Pola Bagi Hasil Tangkapan Ikan Nelayan Pancing Di Cisolok." Albacore 2(1) (2018): 79-91.

Sudaryanto, Agus. "Praktik Bagi Hasil Perikanan Di Kalangan Nelayan Pandangan Wetan, Rembang, Jawa Tengah.” Mimbar Hukum 21(3) (2009): 409-28.

Suryawati,Chriswardani."MemahamiKemiskinansecaraMultidimensional." Jurnal Manajemen Pelayanan Kesehatan 08, no. 03 (2005): 121-29.

Triyanti, Riesti, and Maulana Firdaus. "Tingkat Kesejahteraan Nelayan Skala Kecil Dengan Pendekatan Penghidupan Berkelanjutan Di Kabupaten Indramayu." Jurnal Sosial Ekonomi Kelautan Dan Perikanan 11, no. 1 (2016): 29-43. https://doi.org/10.15578/jsekp.v11i1.3170.

Wardah, Eva. "Peran Lembaga Hukum Adat Laot Dalam Mengatur Sistem Bagi Hasil Perikanan Tangkap Antar Nelayan Dengan Pemodal Di Kabupaten Aceh Barat." Acta Aquatica 2, no. 2 (2015): 75-78.

Widiantoro, Danu Wiki. "Analisis Perjanjian Bagi Hasil Perikanan Antara Pemilik Kapal Dengan Anak Buah Kapal Di Kabupaten Batang." Universitas Muhammadiyah Surakarta, 2018.

Wiyono, ES, and RI Wahju. "Perhitungan Kapasitas Penangkapan (Fishing Capacity) Pada Perikanan Skala Kecil Pantai. Suatu Penelitian Pendahuluan." In Prosiding Seminar Nasional Perikanan Tangkap, 38189. Bogor: Departemen Pemanfaatan Sumberdaya Perikanan. Fakultas Perikanan dan Ilmu Kelautan. Institut Pertanian Bogor, 2006. 